\title{
INTERACTION OF K AND B IN THE INTENSITY OF COFFEE RUST IN NUTRIENT SOLUTION
}

\author{
Gabriel Brandão Vascoํㅡ, Edson Ampélio Pozza², Marília Goulart da Silva ${ }^{3}$, \\ Adélia Aziz Alexandre Pozza ${ }^{4}$, Eugênio Chaves ${ }^{5}$
}

(Received: September 08, 2017; accepted: November 29, 2017)

\begin{abstract}
This study aimed at assessing the interaction of potassium $(\mathrm{K})$ and boron $(\mathrm{B})$ in the coffee rust intensity in a nutrient solution. The experiment which was performed in a greenhouse was set up in the randomized complete block design (DBC) with four replicates. The experimental unit involved a single vase with two Catuai Vermelho (IAC 144) cultivars. The treatments included five doses of boron $(0.05,0.50,1,2$ and $\left.4 \mathrm{mg} \mathrm{L}^{-1}\right)$ and five of potassium $\left(4.0,5.0,6.0,7.0\right.$ and $\left.8.0 \mathrm{mmol} \mathrm{L}^{-1}\right)$, totaling to 25 treatments in a factorial variance analysis. All the coffee seedling leaves were inoculated with Hemileia vastatrix. For the next 24 hours, the vases were covered with a black plastic bag, and left in the greenhouse to ensure favorable conditions for the fungal infection. A significant interaction was observed between the potassium $(\mathrm{K})$ and boron $(\mathrm{B})$ nutrients in coffee rust intensity. As the boron dose increased from 0.05 to $2.0 \mathrm{mg} \mathrm{L}^{-1}$, the coffee rust intensity was observed to rise. From the $0.50 \mathrm{mg} \mathrm{L}^{-1}$ dose of $\mathrm{B}$ a drastic drop in the dry plant mass was observed, which reached zero index at the highest boron dose due to phytotoxicity.
\end{abstract}

Index terms: Hemileia vastatrix, plant nutrition, potassium, boron.

\section{INTERAÇÃO DO K E DO B NA INTENSIDADE DA FERRUGEM DO CAFEEIRO EM SOLUÇÃO NUTRITIVA}

RESUMO: Objetivou-se avaliar a interação do potássio (K) e do boro (B) na intensidade da ferrugem do cafeeiro em solução nutritiva. $\mathrm{O}$ experimento foi realizado em casa de vegetação. $\mathrm{O}$ delineamento experimental foi em blocos casualizados (DBC), com 4 repetições, sendo a unidade experimental constituída por um vaso, com duas mudas do cultivar Catuaí Vermelho (IAC 144). Os tratamentos consistiram de cinco doses de boro $\left(0,05 ; 0,50 ; 1 ; 2\right.$ e $\left.4 \mathrm{mg} \mathrm{L}^{-1}\right)$ e cinco doses de potássio $(4,0 ; 5,0 ; 6,0$; 7,0 e $\left.8,0 \mathrm{mmol} \mathrm{L}^{-1}\right)$, totalizando 25 tratamentos em esquema fatorial de análise de variância. A inoculação foi realizada em todas as folhas das mudas de cafeeiro até o ponto de escorrimento. Posteriormente, os vasos foram cobertos com saco plástico preto por 24 horas, permanecendo na casa de vegetação com o objetivo de proporcionar condições adequadas para o fungo penetrar e iniciar o processo de infecção. Ocorreu interação significativa entre os nutrientes potássio (K) e boro (B) na intensidade da ferrugem do cafeeiro. A partir da dose de 0,05 até $2,0 \mathrm{mg} \mathrm{L}^{-1}$ de B foi observado aumento da intensidade da ferrugem do cafeeiro. A partir da dose $0,50 \mathrm{mg} \mathrm{L}^{-1}$ de $\mathrm{B}$ houve redução drástica da massa da planta seca, atingindo índice zero na maior dose de $\mathrm{B}$, devido a fitotoxidez.

Termos para indexação: Hemileia vastatrix, nutrição de plantas, potássio, boro.

\section{INTRODUCTION}

Over the last 10 years in Brazil, the gross domestic product (GDP) revealed variations in responses to the economic moment. In light of this fact, agribusiness clearly emerged as the principal support of the economy and accounted for good outcomes in the trade balance. Coffee ranks high among the main agribusiness crops. The production for the 2016/2017 harvest was estimated at 45,5 million bags, with the southern state of Minas Gerais being the highest producing region, accounting for around $29 \%$ of the national production (CONAB, 2016). However, diseases are some of the main factors that reduce coffee productivity and the beverage quality. Coffee rust (Hemileia vastatrix, Berkeley \& Broome) is one of the plant pathogens that causes up to $50 \%$ production loss.

Under field conditions however, the disease may vary in intensity based on the method of crop management, pending crop load, irrigation system, soil fertility, and mineral nutrition provided to the plants (LIMA et al., 2010; CUSTÓDIO et al., 2011). When the water, soil fertility and plant mineral nutrition are managed well and balanced accurately, it can be a complementary or alternative means of minimizing and managing diseases, as they play a crucial role in producing resistance barriers against disease (CARRE-MISSIO et al., 2009; PINHEIRO et al., 2011; DORNELAS et al., 2015; PEREZ et al., 2017), and the effect of the phytopathogenic activity of the plant.

1,2,3,5 Universidade Federal de Lavras/UFLA - Departamento de Fitopatologia/DFP - Cx. P. 3037 - 37.200-000 - Lavras - MG gabriel_b_vasco@hotmail.com, eapozza@dfp.ufla.br, mariliagoularts@gmail.com, eugenio_chaves@yahoo.com.br ${ }^{4}$ Universidade Federal de Lavras/UFLA - Departamento de Ciência do Solo/DCS - Cx. P. 3037 - 37.200-000 - Lavras - MG adelia.pozza@dcs.ufla.br 
Potassium (K) and boron (B) are the important minerals that affect plant metabolism. Potassium is mainly responsible for the development of the root, controls the turgidity of plants, the transport of sugars and helps in the formation of enzymes and proteins (TAIZ \& ZEIGER, 2013; PERDIGÃO et al., 2010). $\mathrm{B}$ influences the metabolism of phenols and ribonucleic acid (RNA), translocation of sugars, gibberellic acid activity and amylase action. Besides, the $\mathrm{K}$ is vital to cell wall structure, lignification and maintenance of higher stability of the plasma membrane, as well as lowers the extravasation of the $\mathrm{K}$, sugars and amino acids, thus contributing towards a reduction in the intensity of diseases (DORDAS, 2008; MARSCHNER, 2012). In coffee, Carvalho et al., (1996) noted a higher incidence of rust at low $\mathrm{N}$ and $\mathrm{K}$ concentrations. In the case of nutrient $\mathrm{B}$, no significant difference was reported for coffee rust. However, DORDAS (2008) and MARSCHNER (2012) recorded that the deficiency of B interfered with the incidence of diseases.

Then, this study aimed at evaluating the effect of the K and B nutrients on the intensity of coffee rust in nutrient solution.

\section{MATERIAL AND METHODS}

Employing the randomized complete block design (DBC) for the experiments, four replicates were done. Each experimental unit was a single vase with two plants. A total of 25 treatments were done, involving five doses of B $(0.05,0.50,1,2$ and $4 \mathrm{mg} \mathrm{L}^{-1}$ ) combined in a factorial analysis of variance with five doses of $\mathrm{K}(4.0,5.0,6.0,7.0$ and $8.0 \mathrm{mmol} \mathrm{L}^{-1}$ ). Under greenhouse conditions, the mean temperature and relative humidity were maintained at $21^{\circ} \mathrm{C}$ and $78 \%$, respectively, during the time of the experiments.

To prepare the seedlings, the Catuai Vermelho (IAC 144) was immersed in tap water for 3 hours. They were then disinfested first with $50 \%$ alcohol for 50 seconds, and with $1 \%$ sodium hypochlorite for 1 minute and finally rinsed thrice in distilled sterilized water. Next, they were seeded in $0.50 \mathrm{~m} \times 0.35 \mathrm{~m} \times 0.15 \mathrm{~m}$ plastic trays containing washed sand. After the first pair of cotyledon leaves emerged, the seedlings were watered for 15 days, first with $20 \%$ of the solution strength followed by $50 \%$ ionic strength.

The seedlings were then subjected to the treatments calculated to supply the $\mathrm{K}$ doses, using $\mathrm{NH}_{4} \mathrm{NO}_{3}, \mathrm{Ca}\left(\mathrm{NO}_{3}\right) 2.4 \mathrm{H}_{2} \mathrm{O}, \mathrm{KNO}_{3}, \mathrm{KCl}, \mathrm{KH}_{2} \mathrm{PO}_{4}$,
$\mathrm{MgSO}_{4} \cdot 7 \mathrm{H}_{2} \mathrm{O}$ and $\mathrm{CaCl}_{2} \cdot 6 \mathrm{H}_{2} \mathrm{O}$ as the macronutrient sources. To provide the micronutrients $1.0 \mathrm{~mL}$ $\mathrm{L}^{-1}$ of the stock solution was used, composed of $\mathrm{ZnSO}_{4} \cdot 7 \mathrm{H}_{2} \mathrm{O}\left(0.22 \mathrm{~mL} \mathrm{~L}^{-1}\right), \mathrm{MnSO}_{4} \cdot 4 \mathrm{H}_{2} \mathrm{O}(3 \mathrm{~mL}$ $\left.\mathrm{L}^{-1}\right), \mathrm{CuSO}_{4} \cdot 5 \mathrm{H}_{2} \mathrm{O}(0.08 \mathrm{~mL} \mathrm{~L}-1), \mathrm{H}_{2} \mathrm{MoO}_{4} \cdot \mathrm{H}_{2} \mathrm{O}$ $\left(0.02 \mathrm{~mL} \mathrm{~L}^{-1}\right)$ and Fe-EDTA solution $(1.0 \mathrm{~mL}$ $\left.\mathrm{L}^{-1}\right)$. The boric acid was later added, based on the treatments, in the established dosages. The nutrient solution was continuously aerated via an air compressor connected through hoses to the vases. The solution $\mathrm{pH}$ was monitored every week and maintained between 5.5 and 6.0 by add $0.1 \mathrm{~mol} \mathrm{~L}^{-1} \mathrm{HCl}$ or $0.1 \mathrm{~mol} \mathrm{~L}^{-1} \mathrm{NaOH}$. Whenever required distilled water was added to fill up the vessel volume. The exchange of this solution was done in the different treatments, when the $\mathrm{NO}_{3}^{-}$ depletion monitored with the Horiba ${ }^{\circledR}$ Card for this anion achieved $70 \%$ of the initial concentration.

The $H$. vastatrix inoculum was obtained by first collecting the leaves of the Catuai Vermelho cultivar that exhibited signs of rust in the field. These leaves were then placed in the humid chamber for 24 hours. Next, were washed with deionized water using a brush, and the suspension was conditioned in a glass Becker. The concentration of the suspension was calibrated in a hemocytometer and adjusted to $1.5 \times 10^{4}$ urediniospores $\mathrm{mL}^{-1}$. All the coffee seedling leaves were inoculated up to drainage point just, when the night period began. After the inoculation, the plants were left covered with black plastic bag for 24 hours in the greenhouse to ensure total darkness as well as complete leaf wetness and enable fungal penetration, thus triggering the infectious process.

The assessments were done on the 48th day after inoculation (DAI) when the first disease symptoms were noticed. Every seven days assessments of the disease incidence and severity were done, for a total of nine evaluations. The incidence of the disease was calculated by the percentage of disease leaves compared with the total number of leaves on coffee seedlings.

The disease severity was assessment by the total number of lesions per leaf and the disease leaf area was determined with the diagrammatic scale proposed by Cunha et al. (2001).

The values thus arrived at for coffee rust evaluation were integrated in an area under the incidence of the disease progress curve (AUIDPC) and severity (AUDSPC) of the disease.

Once the assessments were taken, the roots and aerial organs, leaves and branches of the seedlings were collected and nutrition analysis 
was done. After washing the samples in distilled water, they were individually packed in paper bags and oven dried at $60^{\circ} \mathrm{C}$ until constant weight was achieved. Post drying, the plant material was weighed and then the root and shoot materials were ground. The results were expressed in mass $(\mathrm{kg})$ of dry roots (MR), dry aerial parts (MPA) and total (MR + MPA). After the aerial portions of the samples were weighed they were sent to the laboratory for analysis to determine the $\mathrm{K}$ and $\mathrm{B}$ concentrations.

To perform the statistical analysis and compare the treatments, the SAS ${ }^{\circledR}$ v. 93 statistical program was employed. The data on the AUIDPC, AUDSPC, root mass, dry and total aerial parts and nutrient contents drawn from the leaf analyses were subjected to the analysis of variance. The variables in the $F$ test $(\mathrm{P}<0.05)$ showing significance were then submitted to an adjustment of the linear regression models. When the interaction showed significance, the Sigmaplot ${ }^{\circledR}$ program was used to plot the response surface graphs.

\section{RESULTS AND DISCUSSION}

A significant $(p<0.05)$ interaction between the $\mathrm{K}$ and $\mathrm{B}$ nutrients for the area under the incidence of the disease progress curve (AUIDPC) and severity (AUDSPC) of the coffee rust (Figure 1 and 2) was observed.

The lowest AUIDPC and AUDSPC values were seen up to $B$ doses of $1 \mathrm{mg} \mathrm{L}^{-1}$. Above that dosage an exponential increase in the disease was observed, but with a sharp drop from the B dose of 2 to $4 \mathrm{mg} \mathrm{L}^{-1}$. The highest AUIDPC was obtained between the 6.0 and $7.0 \mathrm{mmol} \mathrm{L}^{-1}$ dose of $\mathrm{K}$ and $2.0 \mathrm{mg} \mathrm{L}^{-1}$ dose of B.

No significant interactions were seen between $\mathrm{K} \times \mathrm{B}$ in the dry root mass (MR), shoot (MPA) and total (MR + MPA) variables. However, the $\mathrm{B}$ nutrient alone was seen to affect these variables (Figure 3 ). As the $\mathrm{B}$ doses increased, the mass $(\mathrm{kg})$ of both the roots and shoots decreased. At the 0.05 and $0.50 \mathrm{mg} \mathrm{L}^{-1}$ doses, the highest total masses of the dry plant were observed at values of 8.51 and $8.07 \mathrm{~g}$, respectively. At the highest B dose, which induced plant death, the mass was close to zero, and consequently no disease was evident.

Nable et al., (1997) reported that the B present in excess in the plant tissues can cause leaf death and consequently the death of the entire plant. In this study, the dramatic decrease in the plant dry mass was due to the B-induced phytotoxicity. The plants revealed reduced growth due to necrosis occurring in the apical meristems, exhibiting symptoms similar to those caused by B deficiency, resulting in death at the highest dose. In the young plants, the symptoms are more severe because of the dose being applied at the higher concentration level compared with the smaller leaf area. Thus, no pathogenic infection was evident in the necrotic areas.

The analysis of the aerial plant parts revealed no significant interaction between the $\mathrm{K}$ and $\mathrm{B}$. However, the supply of B in the nutrient solution significantly affected the concentration of $\mathrm{B}$ and $\mathrm{K}$ in the leaf (Figures $4 \mathrm{~A}$ and $4 \mathrm{~B}$, respectively). From the lowest $\mathrm{B}$ dose $\left(0.05 \mathrm{mg} \mathrm{L}^{-1}\right)$ provided via the nutrient solution up to $1 \mathrm{mg} \mathrm{L}^{-1}$, an increase in $\mathrm{B}$ was seen in the leaves, after which a decline was seen and zero content was reached. Whereas for the leaf content of $\mathrm{K}$, the highest $\mathrm{K}$ concentration was evident when the B dose was at its least, and there was a remarkable drop in the $\mathrm{K}$ content in the coffee leaves.

Some studies report the direct influence of $\mathrm{B}$ on pathogen growth and development beyond their functions in plant metabolism. Shi et al., (2012) in their work with the Colletotrichum gloeosporioides pathosystem in mango culture recorded the borate treatment produced an accumulation of the reactive oxygen species (ROS) in the fungal spores, damaging the mitochondria. Besides, the B could also be possibly linked with the disruption of the pathogen cell membrane (QIN et al., 2010), which in turn could inhibit the pathogen spore germination. Earlier, Quin et al., (2010) in their study of the Botrytis cinerea fungus in the grape cultivation reported boron exerting an effective control of the gray mold on the grape berries.

Coffee is most sensitive to deficiency and more highly responsive to B application (BROWN \& SHELP, 1997). This implies that the coffee plant has a narrow sufficiency range of $\mathrm{B}$, ranging between 40 and $90 \mathrm{mg} \mathrm{kg}-1$ in the leaves (MARTINEZ et al., 2003). Besides, the excess boron which causes both the deficiency and toxicity induces a decrease in the root system caused by the death of the root ends (NABLE et al., 1997), which minimizes its water and nutrient absorbing efficiency.

The B-induced toxicity, accompanied by a decrease in the root and shoot mass, triggered a nutritional imbalance in the plant, affecting the $\mathrm{K}$ absorption. Power \& Woods (1997) reported that the potassium absorption rises with the addition of Boron and almost ceases to occur when it is absent; in fact, in several instances the apparent lack of potassium may in reality be boron deficiency. 

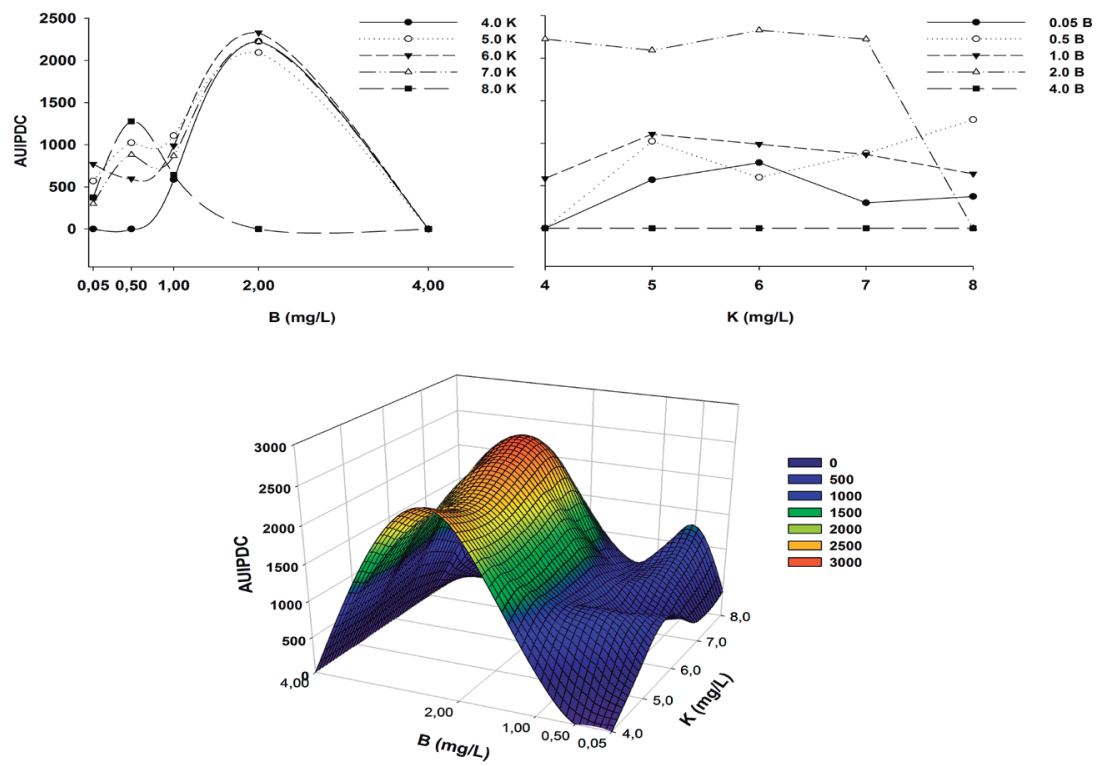

FIGURE 1 - The area under the incidence of the disease progress curve (AUIDPC) of coffee rust (Hemileia vastatrix) in response to the potassium and boron doses in nutrient solution. UFLA, Lavras, MG, 2017.
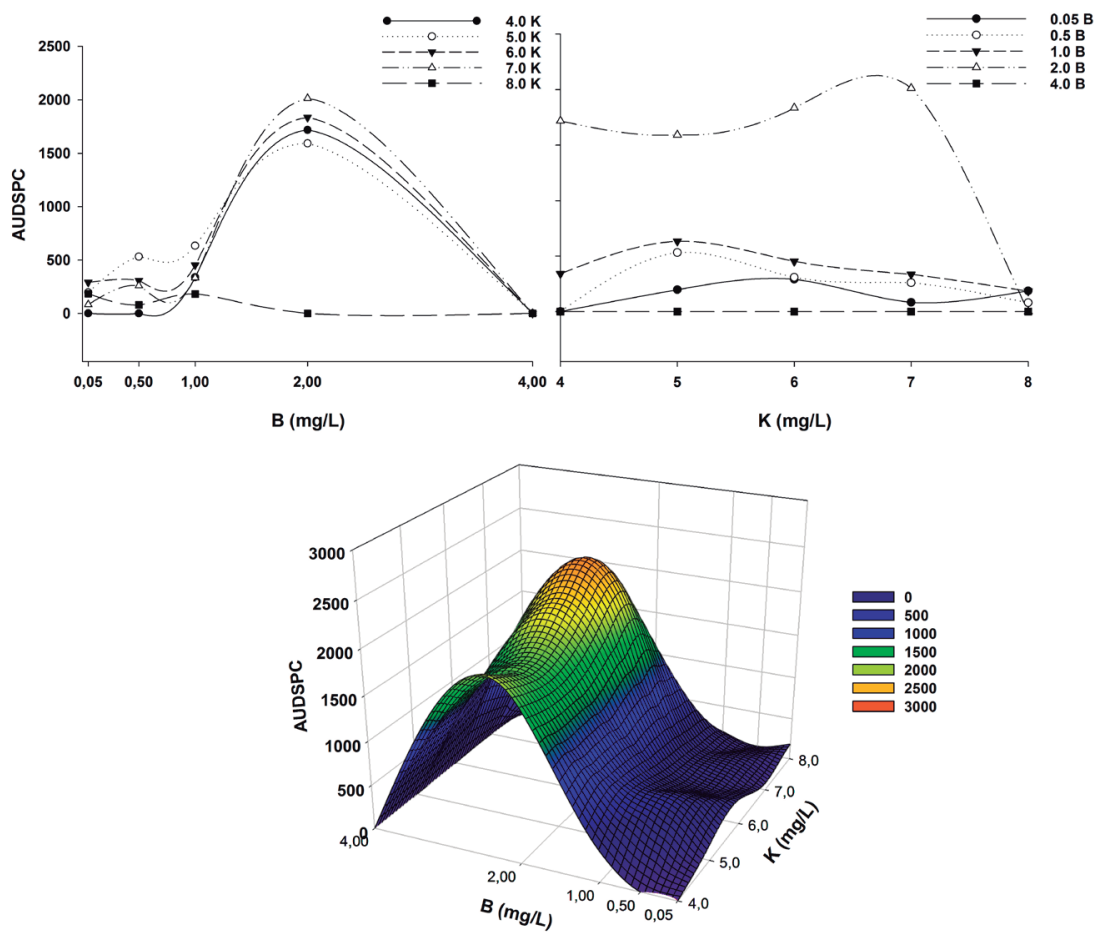

FIGURE 2 - The area under the severity of the disease progress curve (AUDSPC) of coffee rust (Hemileia vastatrix) in response to the potassium and boron doses in nutrient solution. UFLA, Lavras, MG, 2017. 


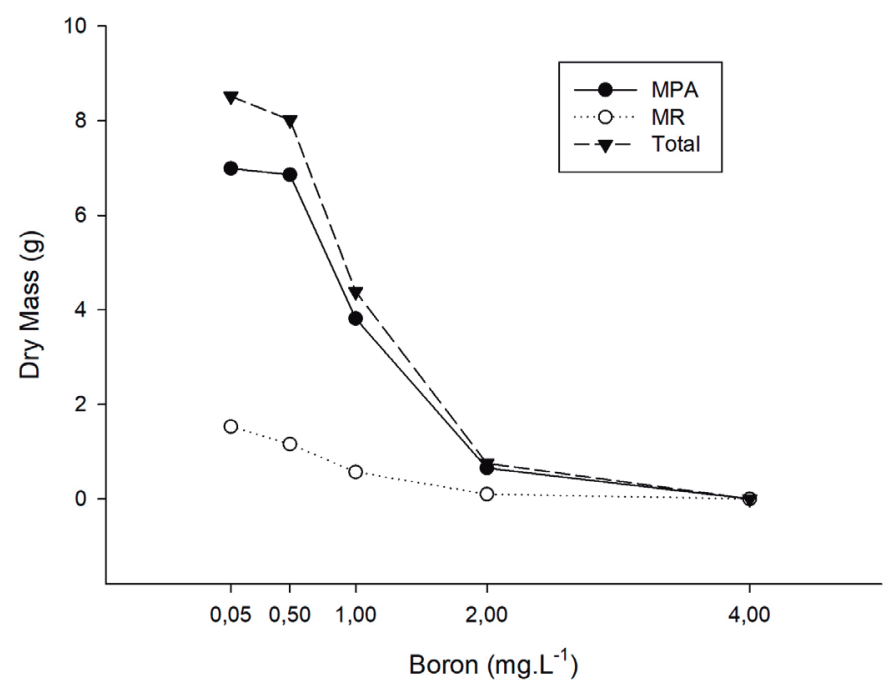

FIGURE 3 - Dry Root Mass (MR), shoot (MPA) and total (MR + MPA) as a result of the boron doses in the nutrient solution. UFLA, Lavras, MG, 2017.

A

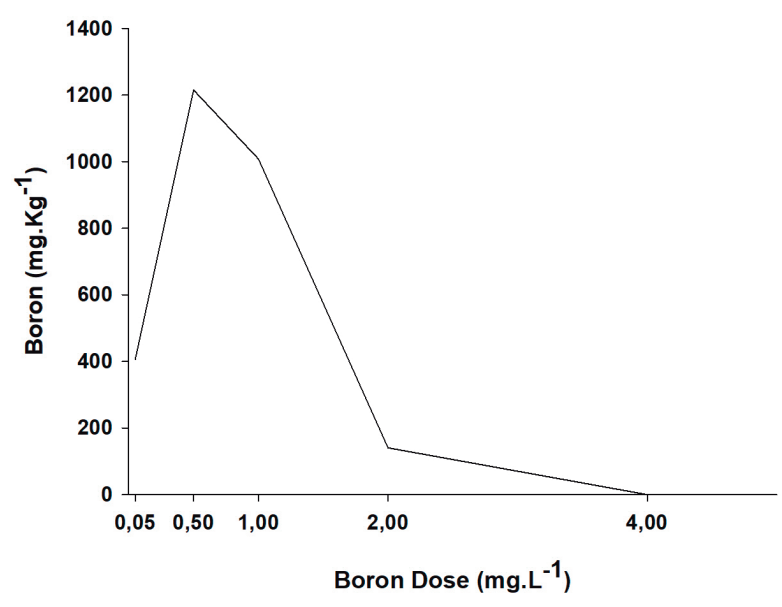

B

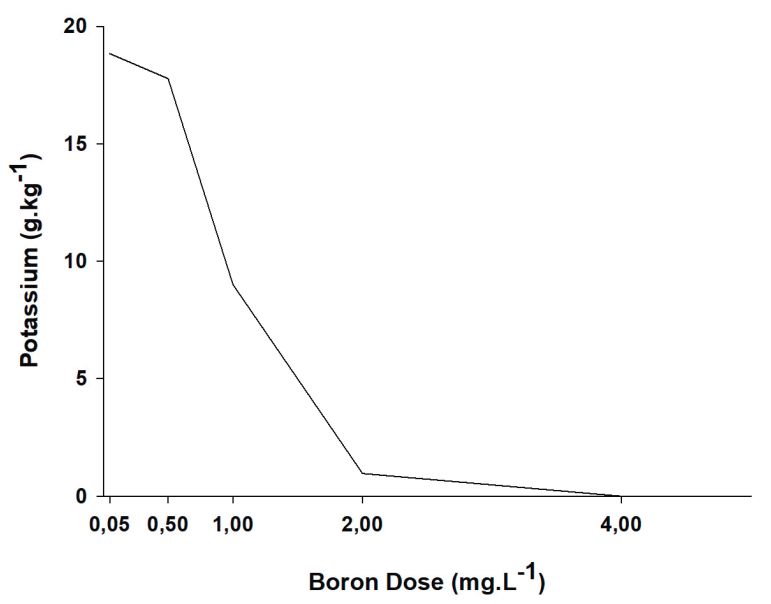

FIGURE 4 - Nutritional levels of B (A) and K (B) resulting from the boron doses in the nutrient solution. UFLA, Lavras, MG, 2017.

Thus, the lower K concentration contributed towards a decrease in the total mass of the plant, because the role of this element is to maintain cellular osmotic equilibrium (MARSCHNER, 2012), as well as activate the enzymes influencing the respiratory and photosynthetic processes, vital to plant growth and development.

Apart from these functions, Brown et al., (2002) reported that plants having ideal boron levels, decrease the extravasation of $\mathrm{K}$, sugars and amino acids, as they play a significant part in the middle lamella formation, endowing the cell wall with a higher degree of resistance to the fungal penetration and colonization, thus lowering the disease severity. Besides, the ideal boron concentration in the plant may be linked to the rise in the production of the reactive oxygen species (ROS) (QIN et al., 2007), which in turn inhibits the fungal growth and development. However, the precise mode of action of boron on fungi remains unclear, and only limited data is available on the effects of boron on fungal metabolism. In this work the inadequate or unbalanced fertilization of these nutrients, resulted in the deficiency of 
$\mathrm{K}$, causing excess sugars in the cytoplasm as well as in the intercellular spaces and on the leaf surface, due to osmotic imbalance, contributing to its accumulation in the plant and serving as a source of energy for plant pests and pathogens (MARSCHNER, 2012). These conditions make leaf tissue susceptible to infection by pathogens. Therefore, it is not possible to generalize the effect of nutrients on plant disease, these can vary depending on the host, the pathogen and the interaction with the nutrients (PEREZ et al., 2017).

\section{CONCLUSIONS}

The interaction of the nutrients potassium (K) and boron (B) in the intensity of coffee rust was observed, under controlled conditions.

The dosage of $B$ in 0.05 to $2.0 \mathrm{mg} \mathrm{L}^{-1}$ was observed to cause an increase in the intensity of coffee rust. From the $0.50 \mathrm{mg} \mathrm{L}^{-1}$ dose of B, a dramatic drop in the dry plant mass was noted, which reached zero at the highest B dose induced by phytotoxicity.

\section{ACKNOWLEDGMENTS}

The authors express their gratitude to the National Council for Scientific and Technological Development (CNPq), the Foundation for Research Support of the State of Minas Gerais (FAPEMIG), the National Coffee Science and Technology Institute (INCT-Café), for the financial assistance provided and scholarships granted. Thanks are also due to the Phytopathology department of the Federal University of Lavras.

\section{REFERENCES}

BROWN, P.H., SHELP, B.J. Boron mobility in plants. Plant Soil, v.193, n. 1-2, p.85-101, June. 1997.

BROWN, P.H. et al. Boron in Plant Biology. Plant Biology, v. 4, n. 2, p.205-223, Mar/Apr. 2002.

CARVALHO, V.L. et al. Influência da produção na incidência da ferrugem do cafeeiro. Pesquisa Agropecuária Brasileira, Brasília, v. 31, n. 6, p. 401405, jun. 1996.

CARRÉ-MISSIO, V. et al. Ineficiência do silício no controle da ferrugem do cafeeiro em solução nutritiva. Tropical Plant Pathology, Brasília, v. 34, n. 4, p. 416421, jul/ago. 2009.

CONAB. Acompanhamento da safra brasileira café. Disponível em: <http://www.conab.gov.br/ OlalaCMS/uploads/arquivos/17_05_18_15_37_37 boletim_cafe_-_maio_2017.pdf $>$. Acesso em: $0 \overline{8}$ de Setembro de 2017.
CUNHA, R.L. et al. Desenvolvimento e validação de uma escala diagramática para avaliar a severidade da ferrugem (Hemileia vastatrix) do cafeeiro. In: SIMPÓSIO BRASILEIRO DE PESQUISA DOS CAFÉS DO BRASIL, 2., 2001, Vitória. Resumos Expandidos... Brasília: EMBRAPA Café, 2001. p. 1001-1008.

CUSTÓDIO, A. A. D. P. et al. Comparison and validation of diagrammatic scales for brown eye spots in coffee tree leaves. Ciência e Agrotecnologia, Lavras, v. 35, n. 6, p. 1067-1076, Nov/Dec. 2011.

DORNELAS, G. A. et al. Nitrogen and potassium fertilization on the yield and intensity of the maize white spot. Revista Ceres, Viçosa, v. 62, n. 4, p. 351359, July/Aug. 2015.

DORDAS, C. Role of nutrients in controlling plant diseases in sustainable agriculture. A review. Agronomy for Sustainable Development, v. 28, n. 1, p. 33-46, Jan/Mar. 2008.

LIMA, L. M. D. et al. Relação nitrogênio/potássio com mancha de Phoma e nutrição de mudas de cafeeiro em solução nutritiva. Tropical Plant Pathology, Brasília, v. 35, n. 4, p. 223-228, jul/ago. 2010.

MARTINEZ, H.E.P. et al. Faixas críticas de concentrações de nutrientes e avaliação do estado nutricional de cafeeiros em quatro regiões de Minas Gerais. Pesquisa Agropecuária Brasileira, Brasília, v. 38, n. 6, p. 703-713, jun. 2003.

MARSCHNER, H. Mineral Nutrition of Higher Plants. 2nd ed. London: Academic, Page 889, 2012.

NABLE R. O.; BANUELES, G.SW.; PAULL, J.G. Boron toxicity. Plant and soil, v. 198, n. 2, p. 181-198, Jan. 1998.

PERDIGÃO, P. C. N. et al. Efeitos de níveis de água e adubação potássica no desenvolvimento do cajueiro anão-precoce, BRS - 189. Revista Brasileira de Ciências Agrárias, Recife, v. 5, n.1, p. 90-94, jan/mar. 2010.

PEREZ, C. D. P. et al. Nitrogênio e Potássio na intensidade da mancha aureolada cafeeiro em solução nutritiva. Coffee Science, Lavras, v. 12, n. 1, p. 60-68, jan/mar. 2017. 
PINHEIRO, J. B. et al. Severidade da ferrugem da soja em função do suprimento de potássio e cálcio em solução nutritiva. Revista Ceres, Viçosa, v. 58, n. 1, p. 43-50, jan/fev. 2011.

POWER, P. P.; WOODS, W. G. The chemistry of boron and its speciation in plants. In: DELL, B.; ROWN, P. H.; BELL, R. W. (eds.). Boron in soil and plants: review. Symposium, Chiang Mai, Reprinted Plant and Soil, v. 193, n. 1-2, p. 1-13, 1977.

QIN, G. Z. et al. Crucial role of antioxidant proteins and hydrolytic enzymes in pathogenicity of Penicillium expansum: analysis based on proteomic approach. Molecular \& Cellular Proteomics, v. 6, n. 3, p. 425438, 2007.
QIN, G. Z. et al. Inhibitory effect of boron against Botrytis cinerea on Table grapes and its possible mechanisms of action. International Journal Food Microbiology, v. 138, n. 1-2, p. 145-150, Mar. 2010.

SHI, X. Q. et al. 2012. Mechanism of antifungal action of borate against Colletotrichum gloesosporiodes related to mitochondrial degradation in spores. Postharvest Biology and Technology, v. 67, p. 138$143,2012$.

TAIZ, L.; ZEIGER, E. Fisiologia vegetal. 5. ed. Porto Alegre: Artmed, 2012. 